\title{
THE GREAT WAR AND ANGLO-AMERICAN LITERATURE:
} BEFORE AND AFTER

\section{Thomas Burns ${ }^{1}$}

\begin{abstract}
This article presents a survey of the important Anglo-American fiction of the First World War (Hemingway, etc.), with special attention given to lesser known works, including foreign authors who influenced this fiction during and after the conflict. Finally, more recent novels about the war will be approached regarding their concern with the recollection of a time one century past.
\end{abstract}

Keywords: First World War; War fiction; Recollection.

Resumo: Este artigo apresenta um panorama da importante ficção anglo-americana (Hemingway, etc.) da Primeira Guerra Mundial, com atenção especial às obras menos conhecidas, incluindo autores estrangeiros que influenciam às obras citadas durante e depois do conflito. Finalmente, alguns romances mais recentes sobre esta guerra serão abordados aqui por sua preocupação com o resgate da memória de uma época de um século atrás.

Palavras-chave: Primeira Guerra Mundial; ficção de guerra; resgate de memória

1 Professor adjunto da Universidade Federal de Minas Gerais - UFMG. 
As befitting a global war, the serious literature emerging from World War I was a world literature, including a number of critically acclaimed works from virtually all the participant nations, many of which were translated into English: the French novels of Henri Barbusse and Jules Romains, the Russian trilogy of Aleksei Tolstoy, the German novels of Erich Maria Remarque, Fritz Unruh, and Arnold Zweig, to give some of the better known examples. Despite their common historical subject, all these works have very different foci, and they were written and published at different times, some of them while the war was still going on, but most in the following decade, the 1920s, as if the reality of the war had to be fully absorbed for several years to write about it. One of the most well-known novels from the continent is Barbusse's Le Feu, whose English translation, Under Fire: The Story of a Squad, was already available by 1917 and could be read by both British soldiers in the trenches and by the American novelist John Dos Passos when he was serving in an ambulance unit in France. In fact, Hemingway's character Frederic Henry, in A Farewell to Arms, reads it while recovering from wounds in Milan, as Malcolm Bradbury (1994) points out. Remarque's novel of the next decade, translated into English as All Quiet on the Western Front (1928), is, like Barbusse's, although from the other side of the trenches, a combat novel that presents the grim experiences of the private soldier telling his own story, a type of narrative that has become a sub-genre of war novels.

The elements that form the bases of virtually all modern combat novels, including those of Barbusse and Remarque, are already present in the American journalist Stephen Crane's The Red Badge of Courage, published in 1895, two decades before the beginning of the Great War, a novel based on the American Civil War of thirty years earlier, although that war is not mentioned by name in the text. One might even say that Crane's prescient novel is a World War I novel avant la lettre. All the relevant themes are there: the novice versus the veteran (or, more abstractly, innocence versus experience), imagined versus real combat (or illusion versus. reality), courage versus cowardice, and the close camaraderie of men in a small unit under fire. This latter theme, the camaraderie of fighting men forged in battle, is perhaps as old as Homer, if we think of Achilles and Patroclus, but the unique experience of the trenches carried the intimacy of men to a new level, creating a sense of isolation from civilian life and a common identity with those who shared their suffering. Historian Stanley Payne puts it like this:

The virtually static trench fronts tied down millions for months on end, creating a new collective consciousness of a separate society, a warrior group partially isolated from the rest of the nation and from normal experience, bonded by a prolonged camaraderie and a new sense of collective identity, a consciousness made more deep and lasting by common suffering and self-sacrifice (PAYNE, 1995, p. 73).

It should be added that while this phenomenon is usually seen to have positive consequences - the "band of brothers" of Shakespeare's Henry V - it need not have, as shown by Payne's argument that this "bonding" would in fact form a basis for Fascist ranks, with Corporal Adolph Hitler, a combatant in the Great War, being only the best known example. 
Remarque's Under Fire and many of the Anglo-American novels have added two more elements that are distinctly modern. The first is the displaced feeling of the veterans on leave or after the war is over, magisterially displayed, for example, in Ernest Hemingway's short story "Soldier's Home". This anomie is a feeling that nearly half a century later would constitute a major theme in the literature of the Vietnam War. The second is the contrast between the grandiose language used to justify war in jingoist propaganda and the stark brutality of the actual experience, a contrast that serves as the basis of much anti-war fiction and film. This contrast is indirectly present in The Red Badge of Courage in the conflict between young Henry Fleming's heroic fantasies and his inability to sustain them in real circumstances. In Remarque's novel, the contrast starkly occurs among the squad members while on leave. In a break from the trenches, they listen with disgust to civilians telling them about the glories of war and how it should be fought.

Other elements present in Crane's work, as well as in the above-mentioned French and German examples, will become characteristic of the Anglo-American fiction of the Great War and even later combat fiction. I might summarize these elements as follows: the psychological anxiety and stress of combat and the emotional numbness it causes in the men; the longing for home and peace, and yet the feeling that such a place and condition are not real; the relentless pursuit of food, drink, and women; the comradeship among fellow soldiers and the emotional strategies for coping with their deaths; the stupidity of the military hierarchy; and the absolute disparity between combat and civilian life. This disparity, as I have suggested, was especially galling to soldiers in the trenches, for, while they were being killed and mutilated, life went on as usual only a short distance away (only 70 miles, for example, from the British lines to the streets of London). The shortness of the geographical distance has been considered by Paul Fussell (1975) as an ironic contrast of the psychological distance of the one world from the other.

Finally, there is a feature specific both to fictional and non-fictional accounts of the Great War: the "pastoral" or "bucolic" interlude, a peaceful break from the trenches that was made possible by the well-defined lines clearly dividing the "front" from the rear. These interludes, as Fussell (1975) argues, are made both more pleasurable and more painful again by the contrast between what the soldiers have endured before this break and what they still have to face on their return to the front.

My title might suggest that I will discuss the more well-known novels of the Great War, like Hemingway's A Farewell to Arms, or the lesser known but equally important novels Frederick March's Company K and Humphrey Cobb's Paths of Glory, all American works, or the English Siegfried Sassoon's fictional autobiographical trilogy Memoirs of George Sherston, but I have done so elsewhere. Here I will discuss a British work that is far less familiar than any of these but that deserves to be better known: Frederick Manning's The Middle Parts of Fortune.

Manning's novel focuses on the experiences of the common soldier in the context of a small unit. Published anonymously in 1929 and republished under a pseudonym ("Private 19022") the following year under the title Her Privates We. Both titles (from Hamlet II, ii) pun on the expression "private parts" of the "strumpet" Fortune. Greatly admired by Hemingway, who thought it the finest war novel ever written, Manning's original version 
featured a language that reflected the rich profanity of soldier's talk, which, despite the author's protests, was censored out of the text and only later restored. Manning generally omits the gruesome descriptions of mutilations that Barbusse and Remarque thought were necessary for telling the truth about the war, perhaps because, unlike those authors, he is not so much writing an anti-war novel as simply trying to give a straightforward account of the line soldier's life, describing with painstaking realism a self-contained world, without questioning the war's ideology, as Bergonzi (1996) suggests.

The Middle Parts of Fortune concentrates, as usual, on a small infantry unit in order to involve the reader in the fates of the individual members, and just like All Quiet on the Western Front, the simple structure begins with the devastated unit returning from combat, and expecting a final attack, with a series of unconnected episodes between the opening and closing actions. The protagonist Bourne and his mates spend a lot of time looking for food and alcohol, but unlike Remarque, there are no contrasting scenes of civilian life or soldiers on leave. In the end, the attack (presumably, the Battle of the Somme) is finally launched with nearly all the men being killed, including Bourne, who is killed by a bullet in the chest.

The absence of the first-person narrator to record how Bourne feels ensures that his death is not in any way a dramatic climax but occurs merely as one more unfortunate but insignificant event in a war made up of such events. The other men, who have all along regarded Bourne as a "good fellow", immediately detach themselves from his memory, no longer referring to him or even mentioning his name, as a means of protecting their own emotional stability. The psychological mechanism at work here is what Robert Jay Lifton, in his work on Vietnam veterans, has called "psychic numbing". or "protection against overwhelming and unacceptable stimuli". The combatant's mind works in a way that is essentially irrational, but, given the circumstances, is a force for self-preservation that has its own psychological logic: "If I feel nothing, then death is not taking place"; "If I feel nothing, I cannot be threatened by death all around me"; and, with respect to other men killed: "If I feel nothing, then I am not responsible for you and your death" (LIFTON, 1973, p. 32).

At this point, given limitations of space, I will simply list the classics of the Anglo-American narrative literature of the Great War, including the fictional and autobiographical works most widely discussed in the critical literature of the war: Richard Aldington, Death of a Hero (1929); Vera Brittain, Testament of Youth (1933); E.E. Cummings, The Enormous Room (1922); John Dos Passos, U.S.A. (trilogy, 1937); Ford Madox Ford, Parade's End (trilogy, 1924-28); Robert Graves, Goodbye to All That (1929); Ernest Hemingway, A Farewell to Arms (1929); T.E. Lawrence, Seven Pillars of Wisdom (1935); William March, Company K (1933); Siegfried Sassoon, The Complete Memoirs of George Sherston (trilogy, 1937); Dalton Trumbo, Johnny Got His Gun (1939); Rebecca West, The Return of the Soldier (1918).

It is important to mention some British novels published about the war in contemporary times The Great War still inspires writers to produce works of fiction, although these are necessarily unlike the combat novels and memoirs of the war years. After the death of the last known veteran, the war can longer be directly remembered, only recovered or "reconstructed." As Barbara Korte observes, "1914-18 has always been a site of memory under construction and reconstruction" (KORTE, 2000, p. 121). In a number of more recent no- 
vels on the Great War, Korte finds certain recurring images and themes in what she calls "retrovisions" of the 1990s. The images include the Western Front as the prominent site of memory, with the men going "over the top" to the sound of an officer's whistle, as in the Battle of the Somme recreated in Sebastian Faulks' Birdsong (1993). Another main theme is shell-shocked and mutilated men, especially those with facial disfigurement, prominent in Robert Edric's In Desolate Heaven (1997), which takes place at a Swiss spa, where a military hospital treats such men until they can be returned home. The novel focuses on two men indirectly, through the thoughts and feelings of a young woman, Elizabeth, who has lost her brother to the war and finds herself incapable of helping her sister-in-law bear the loss. The suffering of veterans, both physical and psychological, as well as that of women who lost men close to them, will be taken up in the other Great War novels of the 1990s.

Some other themes and motifs mentioned by Korte include the Apocalypse, crosses, the idyllic prewar world versus the shattered postwar world, the comradeship of the men, their distrust of the war's purpose, their hatred and mistrust of civilians, and their inability to communicate the experience of combat. Many of these images, themes, and motifs, as has been discussed above, are those of the classic works as well, but the differences from the classic works found in recent fiction reflect some of the revisions in content that have taken place since the 1960s - the war experiences of the lower ranks and the working-class, of women, and of pacifists and Conscientious Objectors. As well as the "sedimented" images and myths of the collective memory of the war, today's writers and filmmakers have had to depend on the earlier literature, which, according to Samuel Hynes, gave the "fullest definition" to the myths of the Great War (KORTE, 2001, p. 122; HYNES. 1990, p. X). The distinguishing feature of the novels of the 1990s, however, is methodological: a concern for how war can be remembered at all, with the authors fictionalizing their own difficulty in representing it.

An apparently "direct" way of recovering the war is by writing a historical novel about it. Such works are still being written about particular events in both world wars, especially those aimed at a popular market. They depend on the reader's general knowledge of the outcome, at the same time as they furnish unfamiliar detail. For example, Gossip from the Forest (1975), by the Australian novelist Thomas Keneally, focuses not on the great battles of the western front or on the home front but on the armistice.

It should be said that the recovery of the Great War in memory through new fictional methods is not a discovery of the novels of the 1990s, for it is one of the main themes of the Canadian novelist Timothy Findley's The Wars (1977). His strategy is to imagine a post-mortem reconstruction of the life of his protagonist by interspersing a straightforward narrative of the events with metafictional devices like descriptions of old photographs of him at various points of his life and contemporary interviews with people who had known him while he was alive. In this way, a time gap is established between past events and present reflections on them.

It is a measure of how powerful the imagery of the Great War still is that it can serve as a parable for a dystopia nearly half a century later. Anthony Burgess, in his futuristic fantasy, The Wanting Seed (1962), does not so much want to represent the war as create a simulacrum of it. Great War battles are staged, where no one clearly understands the rea- 
sons for fighting and antique weapons and tactics are employed for the purpose, as Fussell suggests, of reducing anti-social elements in an overcrowded population.

In her acclaimed Regeneration trilogy, British author Pat Barker offers a careful social reconstruction of the period through a mixture of fictional and historical characters and events. A new version of the war is given by the treatment of the experiences of people, such as pacifists, who do not figure in the classic accounts. New themes for the British Great War novel like gender and homoeroticism join the old ones like courage and social class.

Finally, in Sebastian Faulk's Birdsong (1993), the female protagonist, who is totally ignorant of the war in a world that has all but erased its memory, can only resort to the materials of the historian: the research of a friendly antiquarian, interviews with veterans who knew the old man she has become fascinated with, his photos and letters, and visits to the official sites of memory: the graveyards and the war monuments. All of these recent novels are compelling reading, although they cannot be discussed in any detail in a single article. Suffice it to say that the Great War lives on in Anglophone fiction.

\section{WORKS CITED}

BERGONZI, Bernard. Heroes' Twilight: A Study of the Literature of the Great War. Manchester:

Carcanet, 1996.

BRADBURY, Malcolm. The Modern British Novel. London: Penguin, 1994.

FUSSELL, Paul. The Great War and Modern Memory. Oxford: Oxford UP, 1975.

HYNES, Samuel. A War Imagined: the First World War and English Culture. New York: Atheneum, 1991.

KORTE, Barbara. “The Grandfather's War: Re-imagining World War I in British Novels and films of the 1990s". In: CARTNELL, Debra, HUNTER, I.Q. and WHALESAM, Imelda (Eds.). Retrovisions: Reinventing the Past in Film and Fiction. London, Pluto Press, 2001.

PAYNE, Stanley G. A History of Fascism. Madison: Wisconsin UP, 1995. 